\title{
PENDIDIKAN ISLAM DALAM SPEKTRUM POLITIK PENDIDIKAN NASIONAL
}

\begin{abstract}
Mastur*
Abstract : Discourse on Islamic education will never be separated from the political and cultural dynamics of a society. In the Indonesian context, the dynamics of Islamic education cannot be separated even shackled by the country's political policies and community pluralism which is a reality in Indonesia, both before independence until post-independence Indonesia. Since the first half of the 19th century, the history of Islamic education in Indonesia has begun a new phase marked by shifts and changes in almost all aspects including institutions, methods, curriculum and Islamic education orientation. At that time Islamic education was dominated by traditional educational institutions, namely boarding schools. Islamic education is an integral part of the National Education System. As part of the national education system, Islamic education gets legitimacy for sexuality and has a place to live and develop in Indonesia to meet the educational needs of the Islamic community as a majority citizen. State accommodation for the Islamic education system makes Islamic education systems and institutions have a strong foundation to be developed by supporting funds and attention from the state. Therefore, the state is obliged to develop an Islamic education system as one of the types of religious education in the national education system.
\end{abstract}

Keyword: Islamic Education, National Education Politics

\section{Pendahuluan}

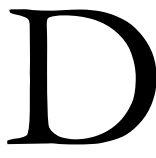

alam sejarah, hubungan antara pendidikan dengan politik bukanlah suatu hal yang baru. Sejak zaman Plato dan Aristoteles, para filsuf dan pemikir politik telah

*IAI Hamzanwadi NW Pancor. mastur@iaihnwpancor.ac.id 
memberikan perhatian yang cukup intens terhadap persoalan politik. Kenyataan ini misalnya ditegaskan dengan ungkapan " $A s$ is the state, so is the school", atau "What you want is the state, tou must put into the school". Selain terdapat teori yang dominan dalam demokrasi yang mengasumsikan bahwa pendidikan adalah sebuah korelasi bagi suatu tatanan demokratis (Nata, 2001).

Dalam sejarah Islam misalnya, hubungan antara pendidikan dengan politik dapat dilacak sejak masa-masa pertumbuhan paling subur dalam lembaga-lembaga pendidikan Islam. Sepanjang sejarah terdapat hubungan yang amat erat antara politik dengan pendidikan. Kenyataan ini dapat dilihat dari pendirian beberapa lembaga pendidikan Islam di Timur Tengah yang justru disponsori oleh penguasa politik. Contoh yang paling terkenal adalah madrasah Nizhamiyah di Bagdad yang didirikan sekitar 1064 oleh Wazir Dinasti Saljuk, Nizham al-Mulk. Madrasah ini terkenal dengan munculnya para pemikir besar. Misalnya, Al-Ghozali sempat mentransfer pengetahuanya di lembaga ini menjadi guru.

Begitu juga halnya dengan pendidikan di Indonesia, berjalan searah dengan peta perpolitikan di Indonesia. Setidaknya perjalananan bangsa Indonesia sudah melalui tiga masa, yaitu Orde lama (1945-1965), Orde Baru (1965-1998), dan Orde Reformasi (1998-sekarang). Kebijakan Pendidikan dari ketiga masa tersebut tidak terlepas dari kebijakan pemerintah. Memang, pendidikan haruslah mengikuti pola kehidupan masyarakat dan sistem kebudayaan yang melatarbelakanginya. Sehinggatidak jarang peralihan atau pergantian dari suatu sistem kekuasaan akan mengakibatkan pula perubahan substansi dalam bidang pendidikan.

Secara umum bahwa pendidikan (dalam konteks politik Indonesia) pada masa ORBA jelas hanya berorietasi mengabdi kepada kepentingan Negara dan penguasa. Penciptaan manusia penganalis sebagimana di canangkan Dr. Daud Yusuf, dalam prakteknya justru merupakan proses pengebirian kebebasan akademik dan kreativitas mahasiswa serta melahirkan para birokrat kampus. Sehingga hasilnya adalah generasi yang apatis dengan lingkungan sekitar namun sangat self-centered. Mereka jelas bukan 
manusia yang dicita-citakan Muhammad Hatta dan Djarir dimana pencerahan, pemahaman, dan penyadaran akan hak dan kewajibannya sebagi anak bangsamenjadi landasan kiprahnya.

Suatu institusi keagamaan atau kemasyarakatan sepertinya sulit dipisahkan dari perkembangan situasi sosial politik yang terjadi di tengah-tengah masyarakat. Sebab setting sosial politik tersebut ikut memberi warna bagi kelangsungan hidup suatu institusi. Hal yang sama juga berlaku bagi pranatasosial lainnya, termasuk di dalamnya pendidikan Islam (sistem dan lembaga) (Nafis, 1995: 507). Perjalanan sejarah telah memperlihatkan berbagai rangkaian historis yang secara terus menerus ditandai dengan pergumulan antara politik dan Pendidikan Islam yang terkadang memihak/menguntungkan dan tidak jarang pula justerumerugikannya. M. Sirozi dalam bukunya Politik Pendidikan menjelaskan bahwa antara pendidikan dan politik atau sebaliknya, adalah dua elemen penting dalam system sosial politik di setiap negara, baik negara maju maupun negara berkembang. Sering dilihat sebagai bagian-bagian yang terpisah, tidak memiliki hubungan apa-apa, padahal kedua-duanya sating menunjang, bahu membahu dalam proses pembentukan masyarakat (Sirozi, 2005: 1).

Di sisi lain menurut pengamatan Mastuhu dikutip Kasiram bahwa ada sejumlah problem mendasar yang harus segera diatasi dalam pendidikan nasional kita yaitu; adanya dualisme sistem pendidikan yang pada gilirannya menghasil kandikotomi antara ilmu agama dan ilmu umum. Sistem Pendidikan kita baik jalur pendidikan agama maupun umum terlalu menekan pada pelatihan ketimbang pendidikan, mementingkan materi ketimbang metodologi, mementingkan produk final ketimbang proses, mengutamakan pemikiran reaktif ketimbang proaktif (Raharjo, 2000: 54). Berbagai problem dialami sistem pendidikan nasional mencerminkan bahwa pendidikan nasional kurang mampu mengakses kepentingan pendidikan Islam sebagai sub sistem pendidikan nasional. Pendidikan nasional harus banyak introspeksi diri sebab pendidikan nasional terlalu bersemangat memikul beban berat di pundaknya. Padahal ia memang tidak kuat memikulnya. Buktinya kegagalan demi 
kegagalan output pendidikan yang dihasilkan tidak akan memuaskan masyarakat, sebab antara landasan teori pendidikan dengan praktek tidak sinkron, demikian juga konsep filosofisnya, pendidikan Islam bersifat universal tetapi pendidikan nasional filosofisnya bersifat lokal (Pancasila).

\section{Refleksi Sejarah Pendidikan Islam Indonesia}

Diskursus tentang pendidikan Islam tidak akan pernah terlepas dari dinamika politik dan kebudayaan suatu masyarakat (Zaman, 2007). Dalam konteks Indonesia, dinamika pendidikan Islam tidak bisa terlepas bahkan terbelenggu oleh kebijakan politik negara dan kemajemukan masyarakat yang merupakan realitas dalam berIndonesia, baik sebelum kemerdekaan hingga pasca kemerdekaan Indonesia. Sejak paruh pertama abad 19, sejarah pendidikan Islam di Indonesia memulai babak baru yang ditandai oleh pergeseran dan perubahan hampir dalam segala aspek yang meliputi kelembagaan, metode, kurikulum serta orientasi pendidikan Islam. Pada masai tu pendidikan Islam didominasi lembaga pendidikan tradisional, yakni pesantren (Ismail, 2010: 173).

Pesantren atau pondok pesantren merupakan lembaga pendidikan Islam tradisional tertua di Indonesia. Pesantren adalah lembaga yang bisa dikatakan merupakan wujud proses wajar perkembangan sistem pendidikan nasional. Sebab, sebelum datangnya Islam ke Indonesia pun lembaga serupa pesantren ini sudah ada di Indonesia dan Islam tinggal meneruskan, melestarikan, dan mengislamkannya. Jadi, pesantren merupakan hasil penyerapan akulturasi kebudayaan Hindu-Budha dan kebudayaan Islam kemudian menjelma menjadi suatu lembaga yang dikenal sebagai pesantren sekarang ini.

Memasuki era kolonialisme, muncul model sekolah yang disediakan oleh pemerintah kolonial Belanda untuk rakyat Indonesia. Pada awalnya model kelembagaan Pendidikan kolonial ini terbatas pada kalangan bangsawan, berupa sekolah kelas satu yakni Hollands Inlandsche school (HIS) dan sekolah kelas dua yakni Standard 
School, yang diselenggarakan dengan tujuan mencetak pegawaipegawai pemerintah.

Selanjutnya akibat perkembangan di wilayah Asia pada khususnya dan negara-negara jajahan, Belanda pun mengembangakan sistem "Sekolah Rakyat" atau "Sekolah Desa" (Volkschoolen) untuk rakyat pribumi secara luas dengan biaya yang murah. Pertengahan abad ke-19. Hal ini menyebabkan lembaga pendidikan tradisional (pesantren, surau, langgar, atau masjid) mendapat saingan secara langsung. Karena sekolah tersebut selain biayanya murah dengan mata pelajaran yang lebih praktis, juga menjanjikan pekerjaan yang bervariasi walaupun pada tingkat rendahan. Hal ini terlihat dari animo masyarakat kala itu yang menjadikan sekolah ala Belanda ini menjadi alternatif pilihan. Pada tahun 1871 terdapat 263 SD dengan jumlah siswa sekitar 16.606 orang, tahun 1892 menjadi 515 SD dengan jumlah siswa52.685 orang, tahun 1910 mencapai 70.000 orang, dan sampaitahun 1914 mencapai 200.000 orang. Pada tahun ini pula pemerintah Belanda mengembangkan pendidikan lanjutanyaitu MULO (Meer Unigebreid Lager Onderwijs) dan AMS. (Mastuki, 2006). Lembaga pendidikan tersebut (HIS, MULO, dan AMS) adalah cikal bakal dari SD, SLTP, dan SLTA saat ini (Ismail, 2010: 174).

Gelombang perubahan ini mencapai puncaknya pada awal abad 20 dengan lahirnya institusi pendidikan Islam yang berbeda baik dengan pondok pesantren maupun dengans ekolah umum Hindia Belanda. Embrio pendidikan Islam yang baru itu bernama madrasah. Kemunculan madrasah menandai abad kebangkitan dan pencerahan (renaissance) dalam pendidikan Islam. Menurut Masykuri Abdilah, pada tahun 1905 sejumlah ulama memperkenalkan sistem "madrasah", yakni dengan penerapan sistem klasikal sesuai dengan sistem Barat, dan sekaligus sebagian mereka bahkan memperkenalkan ilmu pengetahuan umum. Sistem madrasah ini dalam batas-batas tertentu merupakan lembaga persekolahan ala Belanda yang diberi muatan keagamaan. Ini berarti pengaruh Timur Tengah hanyalah salah satu faktor selain perkembangan sosialpolitikdi tanah air pada saat itu (Abdillah, 2002: 78). 
Lebih rinci lagi sebagaimana yang dikemukakan Husni Rahim, bahwa eksistensi dan perkembangan pendidikan Islam di Indonesia berasal dari proses interaksi misi Islam dengan tiga kondisi (Rahim, 2002: 65). Pertama, interaksi Islam dengan budaya lokal-pra Islam yang telah melahirkan pesantren. Sebagian kalangan melihat bahwa pesantren merupakan hasil dari proses akulturasi Islam dengan budaya asli (indigenous) Nusantara. Kedua, interaksi misi pendidikan Islam dengan tradisi Timur Tengah modern telah menghasilkan madrasah. Ketiga, interaksi Islam dengan politik Pendidikan Hindia Belanda telah membuahkan lembaga berbentuk sekolah Islam.

Kemunculan madrasah di awal abad ke-20 disebut sebagai awal pembaruan sistem pendidikan Islam di Indonesia. Di mana, pendidikan pra madrasah tidak mengenal sistem klasikal dengan meja, bangku dan papan tulis sebagai sarana pembelajaran. Meskipun demikian, pesantren dan madrasah memiliki kesamaan yang mendasar, yaitu sama-sama mengajarkan ilmu-ilmu Islam dan kehadiran madrasah merupakan akibat penyesuaian dengan pesantren (Steenbrink, 1994: 23). Sistem pendidikan di madrasah merupakan perpaduan system pondok pesantren dengan sistem pendidikan yang berlaku di pesantren. Sistem pembelajaran tersebut berlangsung secara bertahap, dengan mengikuti sistem klasikal. Sistem pengajian kitab dalam tradisi pesantren mulai diganti dengan bidang-bidang pelajaran tertentu, sekalipun masih menggunakan kitab lama.

\section{Pendidikan Islam Pada Masa Orde Lama}

Pada masa Orde Lama, Lembaga pendidikan Islam pesantren dan madrasah bukan hanya mendapat pengakuan, tetapi juga dukungan dalam bentuk pembinaan dan tuntunan. Wewenang untuk melakukan pembinaan terhadap pesantren dan madrasah sebagai wadah pendidikan Islam itu kemudian diserahkan kepada Departemen Agama. Setelah Indonesia merdeka, pendidikan agama telah mendapat perhatian serius dari pemerintah, baik di sekolah negeri maupun swasta. Usaha tersebut dimulai dengan memberikan 
bantuan sebagaimana anjuran oleh Badan Pekerja Komite Nasional Pusat (BPKNP) tanggal 27 Desember 1945, disebutkan:

"Madrasah dan pesantren yang pada bakikatnya adalah satu sumber pendidikan dan pencerdasan rakyat jelata yang telah berurat dan berakar dalam masyarakat Indonesia pada umumnya, hendaknya mendapatkan perbatian dan bantuan nyata berupa tuntunan dan bantuan material dari pemerintab"

Pendidikan Agama kemudian selanjutnya diatur secara khusus dalam UU No, 4 Tahun 1950 pada bab XII Pasal 20, yaitu:

1. Di sekolah-sekolah negeri diadakan pelajaran agama, orang tua murid menetapkan apakah anaknya akan mengikuti pelajaran tersebut atau tidak.

2. Cara penyelenggaraan pendidikan agama di sekolah negeri diatur dalam peraturan yang ditetapkan oleh Menteri Pendidikan Pengajaran dan Kebudayaan, bersama-sama dengan Menteri Agama.

Perkembangan pendidikan Islam pada masa orde lama sangat terkait pula dengan peran Departemen Agama yang mulai resmi berdiri pada tanggal 3 Januari 1946. Departemen Agama sebagai suatu lembaga pada masa itu, secara intensif memperjuangkan politik pendidikan Islam di Indonesia. Pendidikan Islam pada masa itu ditangani oleh suatu bagian khusus yang mengurus masalah pendidikan agama, yaitu Bagian Pendidikan Agama. Tugas dari bagian tersebut sesuai dengan salah satu nota Islamic education in Indonesia yang disusun oleh Bagian Pendidikan Departemen Agama pada tanggal 1 September 1956, yaitu (Boland, 1985: 56):

1. Memberi pengajaran agama di sekolah negeri dan partikulir,

2. Memberi pengetahuan umum di madrasah

3. Mengadakan Pendidikan Guru Agama serta Pendidikan Hakim Islam Negeri.

Selanjutnya kebijakan pemerintah orde lama dalam bidang pendidikan Agama dan pendidikan Islam secara khusus termaktub dalam SKB Tiga Menteri. Kaitannya dengan hal itu maka khusus untuk mengelola pendidikan agama yang diberikan ke sekolah- 
sekolah umum, maka pada bulan Desember 1946, dikeluarkanlah Surat Keputusan Bersama (SKB) antara Menteri PP dan K dengan Menteri Agama, yang mengatur pelaksanaan Pendidikan Agama pada sekolah-sekolah umum (negeri dan swasta), yang berada di bawah kementrian PP dan K (Boland, 1985: 68). SKB tersebut dapat menjelaskan kepada kita bahwa pendidikan agama (Islam) bagi peserta didik telah dirancang sedemikian rupa mengacu ke UU. No. 4 Tahun 1950. Hal ini juga menunjukkan bahwa telah ada upaya yang dilakukan oleh pemerintah dalam menjamin kehidupan beragama warganya untuk mendapatkan pendidikan agamanya masing-masing. Tak luput pula bagi umat Islam bisa memperoleh pendidikan agama Islam dibangku sekolah mereka (Ismail, 2018: 157).

Selanjutnya Pendidikan Agama ini diatur secara khusus dalamUU Nomor 4 Tahun 1950 pada Bab XII pasal 20. Sementara itu pada Peraturan Bersama Mentri PP dan K dan Mentri Agama Nomor: 1432/kab.tanggal 20 Januari 1951 (Pendidikan), Nomor K 1/652 Tanggal 20 januari 1951(Agama) diatur tentang Peraturan Pendidikan Agama di sekolah-sekolah yaitu pasal 1, 2, 3, dan pasal 4.1

Berdasarkan keterangan di atas, ada 2 hal yang penting berkaitan dengan pendidikan Islam pada masa orde lama, yaitu pengembangan dan pembinaan madrasah dan pendidikan Islam di sekolah umum. Keadaan pendidikan Islam dengan segala kebijaksanaan pemerintah pada zaman Orde Lama. Pada akhir Orde Lama tahun 1965 lahir semacam kesadaran baru bagi umat Islam, di mana timbulnya minat yang mendalam terhadap masalah-masalah pendidikan yang dimaksudkan untuk memperkuat ummat Islam, sehingga sejumlah organisasi Islam dapat dimantapkan. Dalam hubungan ini Kementrian Agama telah mencanangkan rencana-rencana program pendidikan yang akan dilaksanakan dengan menunjukkan jenis-jenis pendidikan serta pengajaran Islam yaitu (Langulung, 2001; 58); Pesantren Indonesia Klasik, Madrasah Diniyah, Madrasah-madrasah swasta, Madrasah Ibtidaiyah Negeri (MIN), Suatu Madrasah Ibtidaiyah Negeri (MIN) 6 tahun, dan Pendidikan Teologi tertinggi, pada tingkat Universitas diberikan sejak tahun 1960 pada IAIN, 
IAIN ini dimulai dengan dua bagian atau dua fakultas di Yogyakarta dan dua Fakultas di Jakarta.

\section{Pendidikan Islam Pada Masa Orde Baru}

Secara umum diakaui bahwa kebijakan pemerintah orde baru mengenai pendidikan Islam dalam konteks madrasah di indonesia bersifat positif dan konstruktif, khususnya dalam dua dekade tarakhir 1980-an sampai dengan 1990-an. Pada masa pemerintahan orde baru, lembaga pendidikan (madrasah) dikembangkan dalam rangka pemerataan kesempatan dan peningkatan mutu pendidikan. Kebijakan seperti ini lebih kuat tercermin dalam komitmen orde baru memandang bahwa pendidikan agama sebagai bagian yang tidak terpisahkan dari sistem pendidikan nasional. Sedangkan pada paruh awal pemerintahan orde baru, kebijakan tentang madrasah bersifat melanjutkan dan meningkatkan kebijakan orde lama. Pada tahap ini madrasah belum dipandang sebagai bagian dari sistem pendidikan nasional, tetapi baru bersifat lembaga pendidikan otonom dibawa pengawasan Mentri Agama. Hal ini disebabkan pendidikan madrasah belum didominasi oleh muatan-muatan agama, menggunakan kurikulum-kurikulum yang belum terstandar, memiliki struktur yang tidak seragam, dan kurang terpantaunya manajemen madrasah oleh pemerintah (Boland, 1985: 46).

Menghadapi kenyataan tersebut diatas, langkah pertama dalam melakukan pembaruan ini adalah dikeluarkannya kebijakan Mentri Agama Tahun 1967 sebagai respons terhadap terhadap TAP MPRS No. XXXVII Tahun 1966 dengan melakukan formalisasi dan strukturisasi madrasah. Formalisasi ditempuh dengan menegrikan sejumlah madrasah dengan kriteria tertentu yang diatur oleh pemerintah disamping mendirikan madrasah-madrasah yang baru. Sedangkan strukturisasi dilakukan dengan mengatur perjenjangan dan perumusan kurikulum sekolah-sekolah yang berada dibawah DEPDIKBUD. Salah satunya tercantum dalam pada pasal 1 TAP MPRS No. XXVII Tahun 1966 "menetapkan pendidikan agama menjadi mata pelajaran disekolah-sekolah mulai dari sekolah dasar sampai ke universitas-universitas negeri. 
Seiring dengan struktur madarsah yang semakin lengkap, pada tanggal 10 sampai 20 agustus 1970 telah diadakan pertemuan di Cibogo, Bogor dalam rangka penyusunan kurikulum madrasah dalam semua tingkatan secara nasional. Langkah ini merupakan kontribusi pemerintah orde baru dalam mendekatkan hubungan hubungan madrasah dengan sekolah. Ototnomi yang diberikan kementrian agama untuk mengelola madrsah terus dibarengi dengan kebijakan yang mengarah pada penyempurnaan sistem pendidikan nasional. Langkah ini menjadi anggenda penting dimasa awal-awal pemerintahan orde baru.

Dalam dekade 1970-an madrasah terus dikembangkan untuk memperkuat keberadaannya, namun diawal-awal tahun 1970-an, justru kebijakan pemerintah terkesan berupaya untuk mengisolasi madrasah dari bagian sistem pendidikan nasional. Hal ini terlihat dengan langkah yang ditempuh pemerintah dengan mengeluarkan suatu kebijakan berupa keputusan presiden (kepres) Nomor 34 tanggal 18 April 1972 tentang "tanggung jawab fungsional pendidikan dan latihan".

Selanjutnya, Kepres Nomor 34 Tahun 1972 ini dipertegas oleh Inpres Nomor 15 tahun 1974 yang mengatur operasionalnya. Dalam TAPS MPRS Nomor XVII Tahun 1966 dijelaskan "agama merupakan salah satu unsur mutlak dalam pencapaian tujuan nasional." Persoalan keagamaan dikelola oleh departemen agama, sedangkan madrasah dalam TAP MPRS Nomor 2 Tahun 1960 adalah lembaga pendidikan otonom dibawah pengawasan Mentri Agama". Dari ketentuan ini departemen agama menyelenggarakan pendidikan madrasah tidak saja bersifat keagamaan dan umum, tetapi juga bersifat kejuruan. Dengan keputusan presiden No. 34 tahun 1972 dan inpres No. 15 tahun 1974, penyelenggaraan pendidikan umum dan kejuruan sepenuhnya berada ditanggung jawab Mendikbud. Secara implisit ketentuan ini mengharuskan diserahkannya penyelenggaraan pendidikan madrasah yang sudah menggunakan kurikulum nasional kepada Depdikbud (Mahfud, 2013: 76). 
Dua kebijakan pemerintah diatas, menggambarkan ketegangan yang cukup kuat antara madrasah dengan pendidikan umum (sekolah). Dalam konteks ini, tampaknya madrasah tidak hanya diisolasi dari sistem pendidikan nasional, tetapi terdapat indikasi kuat untuk dihapuskan. Meskipun sudah adanya usaha penegerian madrasah dan penyusunan kurikulum 1973, tampaknya usaha itu tidak cukup sebagai alasan untuk mengakui madrasah sebagai bagian dari sistem pendidikan nasional. Melihat aspirasi rakyat yang keberatan dengan kebijakan yang dikeluarkan pemerintah, maka pemerintah menyikapinya dengan mengadakan sidang kabinet terbatas tanggal 26 november 1974 yang disepakati tiga mentri (kementrian agama, kementrian pendidikan dan kebudayaan, dan kementrian dalam negeri) yang dikenal dengan "SKB Tiga Mentri" tahun 1975. Kesepakatan tiga menteri itu mengenai "peningkatan mutu pendidikan madrasah".

Memasuki dekade 90-an, kebijakan pemerintah orde baru mengenai madrasah ditujukan secara penuh untuk membangun suatu sistem nasional yang utuh. Dan dengan diundangkannya UU No. 2 tahun 1989, memberikan efek positif terhadap pendidikan agama secara umum dan lembaga pendidikan madrasah khususnya. Indikasi ini terlihat dalam pasal 4 bahwa, pendidikan nasional bertujuan mencerdaskan kehidupan bangsa dan mengembangkan manusia Indonesia seutuhnya, yaitu manusia yang beriman dan bertakwa kepada Tuhan Yang Maha Esa dan berbudi pekerti luhur, memiliki pengetahuan yang mantap dan mandiri serta rasa tanggung jawab kemasyarakan dan kebangsaan (Putra, 2007: 23).

\section{Pendidikan Islam Pada Era Reformasi}

Dalam perkembangan pendidikan Islam terutama pasca pemerintahan Orde Baru, sejak tahun 1998 sampai saat ini yang dikenal sebagai sistem pemerintahan Era Reformasi. Masa ini merupakan era baru dalam sistem pemerintahan Republik Indonesia sebagai koreksi terhadap sistem pemerintahan yang dibangun oleh pemerintah Orde Baru. Gerakan reformasi yang dimotori oleh mahasiswa tahun 1998, pada prinsipnya, mengandung empat 
tuntutan yang hendak diwujudkan, yaitu: 1) demokrasi; 2) kebebasan berpendapat dan berbeda pendapat; 3) keterbukaan; dan 4) otonomi. Keempat prinsip tersebut merupakan reaktualisasi dari nilai-nilai budaya Indonesia sebagai cita-cita Proklamasi Kemerdekaan 1945 (Fadjar, 1999: xviii).

Kemudian sebagai respons atas keempat tuntutan reformasi tersebut, disusunlah kebijakan pemerintah yang termuat dalam UndangUndang Otonomi Daerah Nomor 22 tahun 1999 tentang Pemerintahan Daerah dan Undang-Undang Nomor 25 tentang Perimbangan Keuangan antara Pusat dan Daerah. Selanjutnya, direvisi menjadi Undang-Undang Nomor 32 tahun 2004 tentangPemerintahan Daerah dan Undang-Undang Nomor 33 tahun 2004 tentang Perimbangan Keuangan antara Pemerintah Pusat dan Daerah. Undang-Undang tentang Otonomi Daerah tersebut telah mendelegasikan bidang pendidikan sebagai salah satu system pemerintahan daerah yang dikenal dengan desentralisasi pendidikan. Desentralisasi pendidikan ini merupakan bentuk penyerahan wewenang pemerintah pusat kepada daerah untuk menyelenggarakan pendidikan yang bertujuan agar pengelolaan pendidikan menjadi kewenangan daerah sehingga pengembangan, perencanaan, pelaksanaan, dan evaluasinya diharapkan lebih cepat, tepat, efisien, dan efektif khususnya untuk pemenuhan kebutuhan masyarakat di daerah dalam bidang pendidikan.

Dalam praktiknya Pemerintah Era Reformasi telah melakukan perubahan yang signifikan di bidang Pendidikan dengan mengemban misi baru reformasi pendidikan dan sumberdaya manusia yang bertumpu pada pembangunan bidang pendidikan nasional yang aspiratif, demokratis, dan partisipatif. Sejalan dengan hal itu, terdapat empat isu kebijakanpenyelenggaraan pendidikan nasional yang perlu direkonstruksi dalam rangka otonomi daerah, yaitu; Berkaitan dengan peningkatan mutu pendidikan; Efisiensi pengelolaan pendidikan; Relevansi pendidikan; dan Pemerataan pelayanan pendidikan.

Adapun tujuan dari perubahan system pendidikan nasional di Era Reformasi dalam rangka untuk peningkatan mutu pendidikan 
dan pelayanan pendidikan sesuai dengan kebutuhan dan dinamika yang berkembang dalam kehidupan masyarakat. Menurut Malik Fadjar, untuk mewujudkan keinginan itu, dirumuskan UndangUndang Nomor 20 tahun 2003 tentang Sistem PendidikanNasional. Kebijakan ini bertujuan;

"Termujudnya tatanan kehidupan masyarakat dan bangsa Indonesia yang bermutu sesuai dengan amanat Proklamasi Kemerdekaan 1945, bertekad untuk mewujudkan masyarakat madani Indonesia sebagai suatu masyarakat Pancasilais yang beriman dan bartakwa, memiliki cita-cita dan harapan masa depan, demokratis dan beradab, menjujung tinggi bak-bak. asasi manusia, berakblak mulia, tertib dan sadar bukum, koorporatif dan kompetitif, serta memilik ikesadaran dan solidaritas antargenerasi dan antar bangsa, maju dan mandiri, cakap dan cerdas, kreatif dan bertanggung jawab, serta berwawasan budaya” (Fadjar, 1999: 27)

Maka dalam konteks ini, Departemen Agama sebagai penyelenggara pemerintahan di bidang pendidikan Islam telah merespons arah kebijakan pembangunan bangsa Indonesia di Era Reformasi. Kebijakan ini dikemukakan oleh Husni Rahim selaku Direktur Jenderal Kelembagaan Agama Islam dalam Rakor dengan Komisi IV DPR RI tanggal 26 Juni 2001. Dalam rakor tersebut dikemukakan:

"Pendidikan agama diharapkan dapat menjadi sarana bagi pengembangan pribadi, watak dan akblak mulia peserta didik, serta pada pembentukan sikap dan perilaku berakblak. Pengembangan pribadi, watak, dan akblak. mulia, selain dilakukan oleh Lembaga pendidikan formal, juga oleh keluarga, lembaga sosial keagamaan, dan lembaga pendidikan tradisional keagamaan serta tempat-tempat ibadah. Pendidikan agama sangat strategis sebagai upaya peningkatan sumber daya manusia dan sangat besar peranannya dalam mewujudkan manusia yang berkualitas, karena pada bakikatnya manusia yang berkualitas, yaitu manusia beriman dan bertakwa, hanya terwujud melalui penghayatan dan pengamalan ajaranajaran agamanya." (Rahim, 2001: 3)

Lembaga pendidikan Islam yang fungsi utamanya memberikan pengajaran agama dan umum kepada peserta didik idealnya dapat 
memfungsikan dan mengoptimalkan seluruh potensi pendidikan yang dimiliki oleh peserta didik sekaligus dapat mengaktualisasikan visi dan misi pendidikan nasional. Rumusan visi dan misi pendidikan nasional tersebut ditetapkan dalam Undang-Undang Sisdiknas No. 20 tahun 2003, Peraturan Pemerintah No. 19 tahun 2005 tentang Standar Nasional Pendidikan dan Peraturan Menteri Pendidikan Nasional No. 22 tahun 2006 tentang Standar Isi untuk Satuan Pendidikan Dasar dan Menengah.

Kebijakan di bidang Pendidikan nasional tersebut diharapkan mampu menjamin pemerataan kesempatan pendidikan, peningkatan mutu, dan relevansi serta efisiensi manajemen pendidikan. Peningkatan mutu pendidikan diarahkan untuk meningkatkan kualitas manusia Indonesia seutuhnya melalui olah hati, olah pikir, olah rasa, dan olah raga agar memiliki daya saing menghadapi tantangan global. Peningkatan relevansi pendidikan dimaksudkan untuk menghasilkan lulusan yang sesuai dengan tuntutan kebutuhan berbasis potensi sumberdaya alam Indonesia. Peningkatan efisiensi manajemen pendidikan dilakukan melalui penerapan manajemen berbasis sekolah dan pembaruan pengelolaan pendidikan secara terencana, terarah, dan berkesinambungan (Nasional, 2006: 73).

Dalam konteks ini pendidikan Islam berperan aktif untuk mewujudkan visi dan misi pendidikan nasional tersebut dengan membangun paradigma baru dalam mengembangkan keilmuan Islam di lembaga pendidikan yaitu mengembangkan integrase ilmu agama dan ilmu umum. Oleh karena itu pendidikan Islam senantiasa dapat mengembangkan ilmu pengetahuan dan teknologi yang dilandasi oleh nilai moral dan agama. Penguasaan ilmu pengetahuan dan teknologi dewasa ini menjadi keharusan untuk kemaslahatan dan kemajuan umat Islam di masa kini dan masa datang. Sebab, tanpa penguasaan ilmu pengetahuan dan teknologi yang dilandasi oleh semangat agama, dapat dipastikan bahwa umat Islam akan tertinggal dalam peradaban umatmanusia di masa depan.

Oleh karena itu, lembaga pendidikan Islam senantiasa melakukan revitalisasi baik dari sisi kelembagaan maupun dar isisi keilmuannya. Revitalisasi lembaga pendidikan Islam dalam konteks 
ke depan (global) dapat dipahami dari upaya untuk menarik lembaga pendidikan Islam dalam mainstream yakni lebih berperan dalam pembangunan masyarakat. Untuk itu, lembaga pendidikan Islam dihadapkan pada tantangan untuk mengintegrasikan nilai-nilai ajaran agama dalam ilmu pengetahuan dan teknologi. Dengan kata lain, lembaga pendidikan harus memberi bekal berupa penguasaan ilmu pengetahuan dan teknologi kepada murid atau mahasiswa dan lulusan secara memadai (distinctive competence) (Rahim, 2005: 30).

Tujuan dari itu adalah agar akses terbuka terhadap pendidikan tinggi dalam bidang ilmu pengetahuan dan teknologi dapat dimanfaatkan secara optimal oleh lulusan Lembaga pendidikan ini yang pada akhirnya akan melahirkan ilmuwan yang komit dengan nilai agama (Islam) dalam mengkaji dan mengembangkan ilmu pengetahuan mendatang (pembangungan masyarakat ke depan) (Rahim, 2005: 77). Dengan demikian, apabila hal ini dapat dilakukan di lembaga Pendidikan Islam, maka lembaga ini ke depan dapat dijadikan sebagai lembaga pendidikan alternatif bagi anak bangsa dalam merespons perubahan di era globalisasi. Oleh karena itu, respons negara terhadap kebutuhan umat Islam dengan memasukkan Lembaga pendidikan Islam baik pada tingkat madrasah sampai pada tingkat pendidikan tinggi Islam sebagai pendidikan yang sama dengan sekolah umum dan pendidikan tinggi umum dalam system pendidikan nasional merupakan upaya pemerintah dalam memajukan pendidikan umat Islam di Indonesia.

\section{Pendidikan Islam dalam Konfigurasi Sistem Pendidikan di Indonesia}

Pendidikan di Indonesia selama ini berjalan secara dualisme pendidikan (Umum dan agama), sejak pemerintahan kolonial Balanda memperkenalkan sistem pendidikan yang bersifat sekuler, sementara pendidikan Islam yang diwakili oleh pesantren tidak memperhatikan pengetahuan umum, sampai Indonesia merdeka, meskipun pada awal kemrdekaan masih mewarisi sistem pendidikan yang bersifat dualistis. Pendidikan Islam di Indonesia dalam sejarah penjangnya, mulai pada masa penajajahan sampai Indonesia merdeka 
menghadapi berbagai persoalan dan kesenjangan dalam berbagai aspek, berupa persoalan dikotomi pendidikan, kurikulum, tujuan, sumber daya, serta manajemenpendidikan Islam. Azyumardi Azra mengatakan, pendidikan Islam terlihat dalam penyusunan UU Sisdiknas 2003, walaupun ada sebagian Pasalnya, pemerintah belum merealisasikan secara konsisten, contohnya Pasal 49 ayat 1 tentang anggaran pendidikan. Sementara Huzair Sanaky mengatakan, Upaya pemerintah untuk memperbaiki pendidikan Islam di Indonesia dapat kita lihat komitmen mereka dalam penyusunan UU Sisdiknas 2003, walaupun perbaikannya belum dilakukan secara mendasar, sehingga terkesan seadanya saja (Azra, 1999: 59). Usaha pembaharuan dan peningkatan pendidikan Islam sering bersifat sepotong-sepotong atau tidak komprehensif dan menyeluruh serta sebagian besar sistem dan lembaga pendidikan Islam belum dikelola secara professional (Sanaky, 2004: 9).

Setelah Indonesia merdeka, umat Islam semakin menyadari pentingnya perjuangan Umat Islam dalam meraih kemerdekaan, dan pemerintah berusaha melakukan memperbaiki pendidikan Islam diIndonesia. Sebagai realisasinya Pemerintah Indonesia telah merumuskan dalam undang-undang Republik Indonesia No. 2 Tahun1989 tentang sistem pendidikan Nasional yang diteruskan dengan UUNo. 20 Tahun 2003 yang mengatur pengelenggaraan satu system Pendidikan nasional, sebagai upaya pengintegrasian pendidikan Islam dalam sistem pendidikan Nasional (Jannah, 2013: 163). Sistem pendidikan nasional sebenarnya tidak menominasi system pendidikan Islam Indonesia, dan makna manusia seutuhnya dalam tujuan pendidikan nasional melalui beragam jenis, jenjang, sifat dan bentuk pendidikan atau pelatihan sebagai proses kemanusiaan yang bertindak dalam logika berfikir sebagai makhluk yang berakal dan berbudi, juga sebagai proses pemanusiaan yang mampu menjalankan tugas pokok dan fungsi secara penuh pemegang mandat ilahiah yang merujuk pada hubungan dengan Tuhannya berikut perilaku yang dikehendaki di dalamnya dan mandat kultural yang mengandung makna sebagai insan berbudaya. 
Indonesia, walaupun secara tegas dinyatakan bahwa bukan Negara agama dan bukan pula Negara sekuler, tetapi Negara Pancasila (Assegaf, 2007: 143)., Menurut Bahtiar Effendi, Negara Pancasila, dapat dikatakan bahwa Indonesia mengambil jalan tengah (middle path) antara Negara agama dan Negara sekuler. Rumusan sila pertama Pancasila dan Pasal 29 UUD 1945 Ayat (1) memberikan sifat yang khas pada Negara Indonesia, bukan Negara sekuler yang memisahkan agama dan Negara, dan bukan Negara agama yang berdasarkan pada agama tertentu. Negara Pancasila menjamin kebebasan setiap warga negaranya untuk beragama dan wajib memelihara budi pekerti luhur berdasarkan nilai-nilai Pancasila. Sementara Fuat Hasan Dengan status Negara Pancalisa, maka wajar kalau kemudian Pemerintah Indonesia tetap memandang bahwa agama menduduki posisi penting di negeri ini sebagai sumber nilai yang berlaku (Effendi, 2002: 19).

Secara filosofis, pandangan hidup bangsa tidak bertentangan dengan ajaran Islam, maka pendidikan Islam Indonesia seharusnya mampu menjadi sub sistem pendidikan nasional. Terlebih sejak dikeluarkannya UUSPN Nomor 2 Tahun 1989 dan RUU Sindiknas 2003, yang berwawasan masa depan dan diintrodusirkannya kebijakan link and match dalam pendidikan, merupakan peluang dan sekaligus tantangan bagi sistem dan lembaga pendidikan Islam, khususnya bagi sarjana dan cendekiawan muslim untuk merumuskan rancangan sekaligus mempelopori bangunan pendidikan Islam yang berwawasan masa depan, sesuai dengan misi dasar kata al-Islam, adalah mengislamkan yang berarti menjalankan pendidikan sesuai dengan kebutuhan dan dinamika keislaman. UU No. 20 Tahun 2003 pada Bab II pasal 3, bahwa;

"pendidikan Nasional berfungsi mengembangkan kemampuan dan membentuk watak serta peradaban bangsa yang bermartabat dalam rangka mencerdaskan kehidupan bangsa, bertujuan untuk mengembangkan potensi peserta didik agar menjadi manusia beriman dan bertaqwa kepada Tuban Yang Maha Esa, berakhlak mulia, sehat, berilmu, cakap, kreatif, mandiri dan menjadi warga yang demokratis serta bertanggung jawab". (RI, 2006: 58) 
Dalam hal ini pendidikan agama merupakan tanggung jawab pemerintah dan masyarakat. Di samping sekolah/madrasah formal yang didirikan oleh pemerintah seperti MIN, MTsN, maupun MAN, masyarakat dapat juga menyelenggarakan pendidikan agama, baik formal (pesantren, madrasah), nonformal (taman pendidikan AlQur'an (TPA), majlis taklim) maupun informal (madrasah diniyah). Pasal-pasal yang tertuang dalam UU No. 20 Tahun 2002 tersebut merupakan penempatan posisi Pendidikan Islam sebagai bagian dalam kerangka sistem pendidikan Nasional, bahwa pendidikan Islam merupakan bagian dari sistem pendidikan Nasional. Dalam penjelasan pasal 15 UU Sisdiknas No. 20 Tahun 2003 menyebutkan Pendidikan keagamaan merupakan pendidikan dasar, menengah dan tinggi yang mempersiapkan peserta didik untuk dapa tmenjalankan peranan yang menuntut penguasaan pengetahuan tentang ajaran agama atau menjadi ahli ilmu agama.

UU Sisdiknas 2003 merupakan usaha pemerintah untuk memperbaiki pendidikan Islam di Indonesia, walaupun ada sebagian Pasalnya, pemerintah belum merealisasikan secara konsisten, contohnya Pasal 49 ayat 1 tentang anggaran pendidikan. Upaya perbaikannya belum dilakukan secara mendasar, sehingga terkesan seadanya saja. Usaha pembaharuan dan peningkatan pendidikan Islam sering bersifat sepotong-sepotong atau tidak komprehensif dan menyeluruh serta sebagian besar sistem dan lembaga pendidikan Islam belum dikelola secara professional (Sanaky, 1999: 59). Namun secara umum, dapat dilihat bagaimana posisi agama (pendidikan agama) dalam UU Sisdiknas 2003. dari pelbagai Pasal menerangkan bahwa pendidikan agama sebagai sumber nilai dan bagian dari pendidikan nasional. Pendidikan agama mempunyai peran penting dalam mengembangkan potensi peserta didik untuk memiliki kekuatanspiritual keagamaan, akhlak mulia dan kepribadian muslim (khusus agama Islam) (Jannah, 2013: 170).

Kalau dicermati dari tiap Pasal yang tertuang dalam UU Sisdiknas 2003 di atas, dapat di simpulkan bahwa pendidikan agama (pendidikan Islam) mempunyai posisi yang sangat penting dalam pendidikan nasional. Pendidikan agama lebih menfokuskan diri 
dalam membentuk peserta didik secara aktif mengembangkan potensi dirinya untuk memiliki kekuatan spiritual keagamaan dan ketakwaan kepada Tuhan Yang Maha Esa. Meskipun, pendidikan agama mempunyai peranan penting dalam membentuk peserta didik secara aktif mengembangkan potensi dirinya untuk memiliki kekuatan spiritual keagamaan, ketakwaan kepada Tuhan Yang Maha Esa, dan berperilaku/akhlak mulia, akan tetapi dalam realitas, lembaga pendidikan agama Islam di Indonesia belum berjalan dengan baik, bahkan, pendidikan agama masih dipandang Pendidikan nomor 2 oleh sebagian masyarakat, hal ini terlihat masih rendahnya minat masyarakat untuk menyekolahkan putra/putri mereka ke lembaga-lembaga pendidikan agama, seperti Madrasah maupun pesantren.

Lembaga pendidikan agama menjadi prioritas kedua setelah sekolah. Salah satu alasannya adalah kualitas lembaga pendidikan agama lebih rendah di bandingkan sekolah yang sifatnya umum. Maka Lembaga Pendidikan Islam yang memiliki landasan kuat dari agama dan mendapat jaminan dari undang-undang negara harus melalukan perbaikan dan peningkatan standar mutu pendidikan agar dapat menjadi sebuah lembaga layanan publik yang sangat diminati oleh masyarakat Indonesia yang mayoritas beragama Islam.

\section{Catatan Akhir}

Dinamika pendidikan Islam di Indonesia tidak terlepas dari pengaruh kondisi sosio-politik yang sedang berlangsung di bangsa ini. Perubahan demi perubahan terjadi seiring berlakunya kebijakan penguasa dalam mengatur system pendidikan Nasional. Sehingga pada gilirannya berimplikasi terhadap perkembangan dan laju pendidikan Islam yang sudah dicita-citakan oleh masyarakat Islam Indonesia. Dalam perkembangan sejarah pendidikan Islam di Indonesia terbagi menjadi dua fase yakni sebelum kemerdekaan dan pasca kemerdekaa. Namun tulisan membahas sejarah pendidikan Islam yang berada pada tiga dimensi antara lain; pada era kemerdekaan yang diawali oleh rezim orde baru, kemudian dilanjutkan dengan kebijakan pendidikan Islam pada masa orde lama 
dan terakhir adalah pada era reformasi. Masing-masing kurun waktu tersebut, pendidikan Islam mempunyai ciri khas sesuai dengan kebijakan pemerintah sebagai pemegang kebijakan tertinggi dalam hal ini presiden.

Pendidikan Islam merupakan bagian yang integral dari Sistem Pendidikan Nasional. Sebagai bagian dari sistem pendidikan nasional, pendidikan Islam mendapat legitimasi untuk eksis dan mendapatkan tempat untuk hidup dan berkembang di Indonesia untuk memenuhi kebutuhann pendidikan bagi masyarakat Islam sebagai warga mayoritas. Akomodasi negara terhadap sistem pendidikan Islam menjadikan system dan lembaga pendidikan Islam memiliki landasan kuat untuk dikembangkan dengan support dana dan atensi dari negara. Oleh karena itu, negara berkewajiban untuk mengembangkan sistem pendidikan Islam sebagai salah satu jenis pendidikan keagamaan dalam sistem pendidikan nasional. Dalam sistem pendidikan nasional, pendidikan Islam sebagai sistem pendidikan keagamaan dilaksanakan dalam berbagai jalur yaitu formal, informal dan non-formal.

\section{Daftar Pustaka}

A. Steenbrink, Karel. 1994. Pesantren Madrasah Sekolah Pendidikan Islam dalam Kurun Modern. Jakarta: LP3ES.

Abdillah, Maskuri. 2002. "Pesantren dalam Konteks Pendidikan Nasional dan Pengembangan Masyarakat" dalam Ikhwanuddin dan Dodo Murtadlo. Pendidikan untuk Masyarakat Indonesia Baru. Jakarta: Grasindo.

Assegaf, Abdur Rahman dkk. 2007. Pendidikan Islam di Indonesia. Yogyakarta: Suka Press.

Azra, Azyumardi. 1999. Pendidikan Islam Tradisi dan Modernisasi Menuju Milennium Baru, Jakarta: Logos Wacana Ilmu.

Boland, BJ. 1985. Pergumulan Islam di Indonesia. Jakarta: Grafiti Pers. Effendi, Bahtiar. 2002. Masyarakat, Agama, dan Pluralisme Keagamaan, Yogyakarta: Galang Press.

Fadjar, H.A. Malik et.al, 1999. Tim Nasional Reformasi Menuju Masyarakat Madani Kelompok Pendidikan dan Penembangan SDM, 
Flatform Reformasi Pendidikandan Pengembangan Sumber Daya Manusia, Jakarta: Direktorat Jenderal Pembinaan Kelembagaan Agama Islam Departemen Agama RI.

Fajar A. Malik dalam M. Wahyuni Nafis, Dkk (Tim Editor). 1995. Kontekstualisasi Ajaran Islam; 70 Tahun Prof. DR. H. Munawnir Sadzali, Jakarta: IPHI dengan Yayasan Wakaf Paramadina.

Fathul Jannah. 2013. "Pendidikan Islam dalam Sistem Pendidikan Nasional" dalam Jurnal Dinamika Ilmu, 13 (2), 163.

Haidar Putra. 2007. Sejarah Pertumbuban dan Pembaruan Pendidikan Islam di Indonesi. Jakarta: Kencana Prenada Media Group.

Hasan Langulung Prof. Dr. 2001. Pendidikan Islam dalam Abad Ke-21, Jakarta: Al-Husna Zikra.

Ismail. 2010. "Politik Pendidikan Madrasah Di Indonesia Pasca Kemerdekaan: 1945 - 2003" dalam Jurnal Ta'dib, XV (2), 173.

Ismail. 2016. "Politik Pendidikan Islam Orde Lama 1945-1965 (Study Kebijakan Pemerintah Dalam Penyelenggaraan Pendidikan Islam)" dalam Jurnal Kabilah, I (1), 157.

Jabali Fuad dan Jamhari. 2002. LAIN dan Modernisasi Islam di Indonesia.Jakarta: Logos.

Kaelan. 1996. Filsafat Pancasila. Yogyakarta: Paradigma.

Mahfud, Choirul. 2013. Politik Pendidikan Islam di Indonesia (Studi Analisis Kebijakan Pendidikan Islam Pasca Orde Baru). Surabaya: Disertasi IAIN Sunan Ampel.

Nata, Abudin. 2001. Sejarah Pertumbuhan dan Perkembangan Lembagalembaga Pendidikan Islam di Indonesia. Jakarta: Grasindo.

Rahardjo, Mudjia. 2000. Qua Vadis Pendidikan Islam: Pembacaan Realitas Pendidikan Islam, Sosial dan Pengetabuan. Malang: Cendekia Paramulya.

Rahim, Husni. 2002. Pendidikan Islam Di Indonesia Keluar Dari Eksklusivisme, dalam Pendidikan untuk Masyarakat Indonesia Baru. Jakarta: Grasindo.

Rahim, Husni. 2001. Kebijakan Direktur Jenderal Kelembagaan Agama Islam di Bidang Pendidikan Agama dan Keagamaan Islam. Dokumen Departemen Agama RI. 
Rahim, Husni. 2005. Madrasah dalam Politik Pendidikan di Indonesia. Jakarta: Logos Wacana Ilmu.

Sanaky, Hujair AH. 2004. Paradigma Pendidikan Islam, Yogyakarta: Safiria Insania Press.

Sirozi, M. 2005. Politik Pendidikan, Dinamika Hubungan antara Kepentingan Kekuasaan dan Praktik Penyelenggaraon Pendidikan. Jakarta: Raja Grafindo Persada, 2005.

W hefner Robert dan Muhammad Qasim Zaman. 2007. Schooling Islam: The Culture and politics of Modern Muslim Education. New Jersey: Princenton University Press.

Winarno Surakhmad, 2003. Pendidikean Nasional Senantiasa Jadi Kelinci Percobaan. NTB Post. 